\title{
EKSISTENSI PERMAINAN TRADISIONAL SELODOR PADA ERA 4.0 DI KOTA MATARAM
}

\author{
Indah Nur Fitriana ${ }^{1}$, Ines Maharani Lestari ${ }^{2}$, Kinanti Idha Parameswari ${ }^{3}$, Laela \\ Nazuwa ${ }^{4}$, Liza Handayani ${ }^{5}$, Luh Ayu Sudarmini ${ }^{6}$, Nursaptini $^{7 *}{ }^{*}$ Muhammad Tahir $^{8}$ \\ 1,2,3,4,5,6,7,8 Pendidikan Guru Sekolah Dasar, Fakultas Keguruan dan Ilmu Pendidikan, \\ Universitas Mataram, Mataram, 83233, Indonesia \\ *e-mail:nursaptini@unram.ac.id
}

\begin{abstract}
Abstrak
Penelitian ini bertujuan untuk mengetahui eksistensi permainan selodor pada era 4.0 di Kota Mataram. Pendekatan yang digunakan dalam penelitian ini adalah pendekatan kualitatif deskriptif. Subyek penelitian ini adalah masyarakat suku sasak khususnya di Kota Mataram yang diambil secara purposive sampling. Pengumpulan data dilakukan dengan teknik wawancara, dokumentasi dan observasi. Hasil penelitian bahwa permainan tradisional selodor saat ini sudah jarang dimainkan di wilayah kota Mataram. Keadaan tersebut disebabkan karena teknologi yang semakin berkembang di era 4.0
\end{abstract}

Kata kunci: Eksistensi, permainan tradisional Selodor.

\begin{abstract}
This study aims to determine the existence of Selodor games in the 4.0 era in Mataram City. The approach used in this research is a descriptive qualitative approach. The subjects of this study were the people of the Sasak tribe, especially in the city of Mataram who were taken by purposive sampling. Data collection was carried out by interviewing, documentation, and observation techniques. The results showed that the traditional game of Selodor is rarely played in the city of Mataram. This situation is due to technology that is increasingly developing in the 4.0 era
\end{abstract}

Keyword: Existence, the traditional game of Selodor

\section{Pendahuluan}

Indonesia yang terdiri dari berbagai pulau memiliki keanekaragam budaya yang teraktualisasi baik dalam bentuk fisik maupun non fisik, salah satunya permainan tradisional. Permainan tradisional merupakan suatu aktivitas permainan yang tumbuh dan berkembang pada suatu daerah yang memiliki sarat nilai yang diajarkan secara turun temurun dari satu generasi ke generasi berikutnya (Kurniati, 2016). Permainan tradisional memberikan peran terhadap perkembangan potensi anak seperti perkembangan motorik kasar, motorik halus, sampai kognitif anak (Ikawati, Hastuti Diah Ikawati, Purmadi, Ary, 2018). Selanjutnya berdasarkan hasil penelitian (Andriani, 2012) bahwa permainan tradisional dapat melatih konsentrasi, pengetahuan, sikap, keterampilan dan ketangkasan yang secara murni dilakukan oleh otak dan tubuh manusia. Selain itu, permainan tradisional dapat membangun karakter anak (Nur, 2013). 
Permainan tradisional sangat beragam bentuk dan jumlahnya, namun dapat dikelompokkan menjadi beberapa, yaitu berdasarkan arena, berdasarkan kebutuhan akan alat tertentu, berdasarkan cara bermain, berdasarkan hukuman pihak yang kalah dalam permainan, berdasarkan akibat yang ditimbulkan, berdasarkan maksud yang dikandung. Permainan tradisional meningkatkan kemampuan siswa (Nataliya, 2011).

Salah satu permainan tradisional yang berkembang pada suku sasak yaitu selodor yaitu permainan bersifat kelompok dan dapat dimainkan oleh anak laki-laki maupun perempuan. Permainan tradisional selodor ini mengandung unsur-unsur yang melatih keterampilan, ketangkasan, dan kelincahan dengan memainkan permainan selodor anak banyak melakukan gerakan-gerakan yang mengecoh lawan guna melewati lintasan dan kembali ke titik awal sebagai tanda kemenangan. Namun dengan perkembangan teknologi informasi permainan tradisional selodor sudah jarang ditemukan dimainkan oleh anak-anak sebagaimana hasil penelitian(Nur, 2013) bahwa anak-anak lebih sering memainkan game online. Padahal jika ditinjau lebih dalam, beragam permainan tradisional secara langsung dapat memberikan kontribusi kepada anak-anak diantaranya berupa 1) pembentukan fisik yang sehat, bugar, tangguh, unggul dan berdaya saing. 2) pembentukan mental meliputi: sportivitas, toleran, disiplin dan demokratis. 3) Pembentukan moral bekerjasama, berdisiplin, bersahabat, dan berkebangsaan (Hasanah, 2016).

Permainan tradisional mampu mengembangkan kerjasama, mampu menyesuaikan diri, saling berinteraksi secara positif, mampu mengontrol diri, mampu mengembangkan sikap empati terhadap teman, memiliki kemampuan dalam menaati aturan, serta mampu menghargai orang lain (Kurniati, 2016). Begitu juga dengan permainan tradisional selodor. Oleh karena itu, penulis bertujuan mengkaji tentang eksistensi permainan tradisional selodor pada era 4.0 di Kota Mataram.

\section{Metode Penelitian}

Penelitian telah dilakukan dengan pendekatan kualitatif deskriptif. Adapun penentuan sampel dilaksanakan dengan purposive sampling. Teknik pengumpulan data yang telah dilakukan melalui wawancara, dan observasi dan dokumentasi. Kemudian, teknik analisis data yang peneliti gunakan adalah analisis kualitatif yang dikembangkan Miles dan Huberman. Langkah-langkah tersebut sebagai berikut : (a) reduksi data, (b) penyajian data, (c) penarikan kesimpulan.

\section{Pembahasan}

Berdasarkan hasil wawancara dengan informan 1 bahwa permainan tradisional selodor merupakan salah satu permainan tradisional yang dimainkan secara berkelompok / dimainkan oleh beberapa orang. Cara bermain permainan tradisional selodor ini yakni disesuaikan dengan jumlah pemainnya dan dimainkan di lapangan atau wilayah yang luas. Permainan tradisional selodor ini pernah popular, sekitar tahun 90-an. Namun pada era sekarang, permainan tradisional selodor ini sudah jarang dimainkan, yang disebabkan oleh peralihan permainan ke gadget khususnya daerah perkotaan seperti kota Mataram. Namun Informan 1 menjelaskan bahwa sudah ada upaya yang dilakukan oleh pemerintah dalam melestarikan permainan tradisional selodor ini yakni dengan mengadakan lomba permainan tradisional selodor itu sendiri. Seperti pada tanggal 26-27 Novemvber 2019 pemerintah telah mengadakan festival perlombaan di kota mataram yang salah satu permainannya terdapat permainan tradisional selodor.

Menurut informan 2 selaku guru olahraga SDN 4 Mataram bahwa makna dari permainan tradisional selodor yakni untuk membangkitkan kerjasama antar kelompok Kelompok permainan dibagi menjadi dua tim, yaitu tim penjaga dan tim pemain. Tingkat 
keeksisan dari permainan tradisional selodor ini masih cukup eksis, namun dibeberapa daerah sudah jarang dimainkan. Karena, banyaknya pilihan permainan di zaman sekarang ini serta perkembangan zaman yang semakin berkembang pesat.

Pernyataan ini diperkuat oleh informan 3 yang mengatakan bahwa permainan tradisional selodor yaitu permainan yang melatih kelincahan dan kekompakkan sehingga pemain dapat sekaligus berolahraga. Terkait keeksisan dari permainan tradisional selodor ini, masih dapat dibilang eksis tetapi sudah jarang dimainkan dibeberapa daerah terutama di kota Mataram dikarenakan perkembangan teknologi di era 4.0 ini.

Berdasarkan penjelasan informan 1 Permainan tradisional selodor ini dimainkan dengan cara membuat garis yang berbentuk persegi yang dimana jumlah garisnya disesuaikan dengan jumlah pemain, jadi masing-masing garis akan dijaga oleh tim penjaga. Kemudian tim terbagi menjadi 2 yaitu tim pemain dan tim penjaga. Misalkan dalam tim penjaga terdapat 4 anggota maka pada tim pemain juga harus memiliki 4 anggota.

Dijelaskan lebih detail oleh informan 4 bahwa permainan tradisional selodor dimainkan oleh 2 tim yaitu tim penjaga dan tim pemain, setiap tim terdiri dari minimal 4 anggota. Permainan tradisional selodor ini menggunakan lapangan berbentuk segi empat berpetak-petak yang dibagi menjadi 6 bagian. Kemudian tim penjaga berdiri di garis guna menjaga agar tim pemain tidak bisa masuk kedalam kotak petak yang sudah dijaga oleh tim penjaga. Lalu tim pemain yang masuk harus melewati tim penjaga yang berada di garis dan tim pemain tidak boleh tersentuh oleh tim penjaga. Dan apabila tim pemain di sentuh oleh tim penjaga maka harus diganti, tim pemain menjadi tim penjaga dan begitu sebaliknya.

Berikut dokumentasi permainan tradisional selodor.

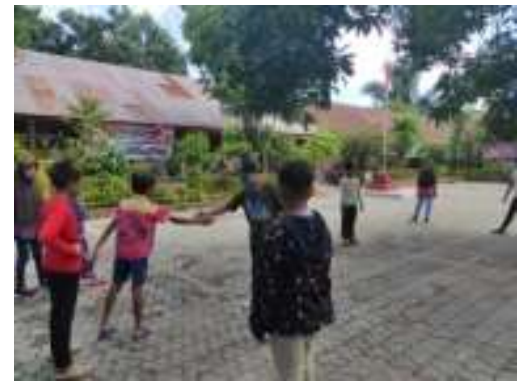

(1)

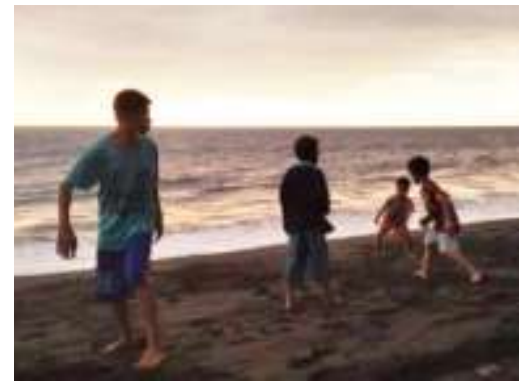

(2)

Gambar 1. Anak bermain permainan tradisional selodor di SDN 4 Mataram.

Gambar 2. Dokumentasi dari narasumber (Anak bermain permainan tradisional selodor di Pantai Gading)

Permainan tradisional selodor merupakan permainan tradisional dengan menggunakan lapangan berbentuk segiempat berpetak petak. Lapangan yang digunakan dibagi dalam enam bagian. Setiap bagian dibatasi dengan kapur tulis. Lapangan yang digunakan harus rata atau datar. Setiap garis dijaga oleh pihak penjaga. Pihak yang akan masuk harus melewati garis dan jika terkena sentuh dari penjaga harus bergantian menjadi penjaga. Permainan tradisional selodor ini dimainkan oleh 2 tim yakni tim penjaga dan tim pemain kemudian setiap tim terdiri dari 5 anggota. Permainan tradisional selodor ini membutuhkan lapangan yang berbentuk persegi dan berpetak yang dimana terdapat garis disetiap petak. Tim penjaga berdiri tepat pada garis dan tim pemain berusaha masuk kedalam kotak berpetak tersebut. Selama permainan berlangsung tim penjaga berusaha menyentuh tim pemain tetapi ruang gerak tim penjaga hanya berada di sepanjang garis saja. Apabila tim 
penyerang berhasil menyentu salah satu tim pemain maka sesi jaga dan pemain ditukar, begitu seterusnya.

Permainan tradisional selodor memang sudah jarang dimainkan. Hal ini disebabkan kurangnya jumlah anggota dan banyaknya permainan yang ada di handphone yang lebih menarik. Hal ini sesuai dengan hasil penelitian (Nur, 2013) bahwa anak-anak lebih sering memainkan permainan modern seperti video games dan games online. Akibatnya permainan anak tradisional mulai terlupakan dan menjadi asing di kalangan anak-anak. Permainan tradisional yang sarat akan budaya, nilai-nilai kebangsaan, bahkan unsur-unsur yang berguna bagi perkembangan anak menjadi terabaikan. Permainan modern yang dianggap lebih praktis bahkan individualistik lebih dipilih pada masa kini oleh anak-anak yang seharusnya mengenal permainan motorik dan kognitif yang lebih baik (Yudiwinata \& Handoyo, 2014). Permainan tradisional mengandung nilai-nilai budaya, yang mulai ditinggalkan (Risdiyanti \& Prahmana, 2018).

Namun berdasarkan hasil wawancara dari beberapa informan menjelaskan bahwa cara yang dapat digunakan untuk mengenalkan permainan tradisional selodor ini dapat dengan cara mengajarkannya atau memasukkannya ke dalam mata pelajaran PJOK. Hal ini dirasa cukup membuat permainan tradisional selodor ini menjadi eksis.

\section{Kesimpulan}

Permainan tradisional selodor sudah jarang dimainkan oleh anak-anak di Kota Mataram. Keadaan ini disebabkan dengan perkembangan teknologi informasi yang banyak menyediakan permainan online, sehingga anak-anak lebih tertarik. Padahal permainan tradisional selodor memiliki manfaat membangun karakter anak baik kerjasama, sosialisasi dan lainnya.

\section{Referensi}

Andriani, T. (2012). Permainan Tradisional Dalam Membentuk Karakter Anak Usia Dini. Jurnal Sosial Budaya, 9(1), 121-136.

Hasanah, U. (2016). Pengembangan Kemampuan Fisik Motorik Melalui Permainan Tradisional Bagi Anak Usia Dini. Jurnal Pendidikan Anak, 5(1), 717-733. https://doi.org/10.21831/jpa.v5i1.12368

Ikawati, Hastuti Diah Ikawati, Purmadi, Ary, Z. (2018). Ragam Permainan Tradisional Suku Sasak Di Pulau Lombok. Prosiding Seminar Nasional Lembaga Penelitian Dan Pendidikan (LPP) Mandala, O(September), 251-253. http://ejournal.mandalanursa.org/index.php/Prosiding/article/view/423/408

Kurniati, E. (2011). Program Bimbingan Untuk Mengembangkan Keterampilan Sosial Anak Melalui Permainan Tradisional. Pedagogia Jurnal Ilmu Pendidikan, 4, 97-114. http://file.upi.edu/Direktori/FIP/JUR._PGTK/197706112001122-

EUIS_KURNIATI/pedagogia.pdf

Kurniati, E. (2016). Permainan tradisional dan Perannya dalam Mengembangkan Keterampilan Sosial anak Panduan Praktis bagi Guru TK/PAUD, SD, Serta Orang Tua. Kencana Prenada Media Group.

Nataliya, P. (2011). Efektivitas Penggunaan Media Pembelajaran Permainan Tradisional Congklak Untuk Meningkatkan Kemampuan Berhitung Pada Siswa Sekolah Dasar. Ilmiah Psikologi Terapan, 03(02), 343-358.

Nur, H. (2013). Membangun Karakter Anak Melalui Permainan Anak Tradisional. Jurnal Pendidikan Karakter, 1, 87-94. https://doi.org/10.1016/j.jsams.2018.05.001 
Risdiyanti, I., \& Prahmana, R. C. I. (2018). Etnomatematika: Eksplorasi dalam Permainan Tradisional Jawa. Journal of Medives: Journal of Mathematics Education IKIP Veteran Semarang, 2(1), 1. https://doi.org/10.31331/medives.v2i1.562

Yudiwinata, H. P., \& Handoyo, P. (2014). Permainan Tradisional dalam Budaya dan Perkembangan Anak. Paradigma, 02, 1-5. 